\title{
Maltodextrin on the flow properties of green coconut (Cocos nucifera L.) pulp powder
}

\author{
Maltodextrina sobre as propriedades de escoamento do pó da \\ polpa de coco (Cocos nucifera L.) verde
}

\author{
Tayla Maria Ramos Araújo' (D), Michael Douglas Lemos Farias' (D), \\ Marcos Rodrigues Amorim Afonso ${ }^{* *}$ (D) José Maria Correia da Costa ${ }^{1}$ (D), Kaliana Sitonio Eça1 (D)
}

${ }^{1}$ Universidade Federal do Ceará/UFC, Fortaleza, CE, Brasil

*Corresponding author: m.r.a.afonso@gmail.com

Received in and February 7, 2020 approved in June 23, 2020

\begin{abstract}
The study of the flow properties and particle surfaces of a food powder is essential for predicting its behaviour during processing and commercialization. The objective of this work was to determine the powder flow properties of lyophilized green coconut pulp with different concentrations of maltodextrin. Samples containing 0,5, 10 and $15 \%(\mathrm{~m} / \mathrm{m})$ maltodextrin were lyophilized, and the flow index (FI), wall friction angles and densities were determined. The microstructure of the powders was evaluated by scanning electron microscopy (SEM). The samples containing 0 and $5 \%$ maltodextrin showed $1.87 \mathrm{Fl}$, classifying them as very cohesive powders, and those containing 10 and $15 \%$ cohesive powder showed 2.12 and $2.43 \mathrm{Fl}$, respectively. The powder densities varied from 138.6 to $287.6 \mathrm{~kg} / \mathrm{m}^{3}$, and the wall friction angle varied from 15.8 to $39.8^{\circ}$. The powder particles presented irregular shapes and rough surfaces, especially in powders containing 0,5 and $10 \%$ maltodextrin. The powder containing 15\% had smoother and less agglomerated surfaces. An increase in the amount of maltodextrin added to the pulp made the particles smoother and denser and improved the fluidity of the powder.
\end{abstract}

Index terms: Flow index; cohesiveness; powder density.

\begin{abstract}
RESUMO
O estudo das propriedades de escoamento e da superfície das partículas de um alimento em pó é essencial para prever seu comportamento durante o processamento e comercialização. O objetivo deste trabalho foi determinar as propriedades de escoamento do pó da polpa de coco verde liofilizada com diferentes concentrações de maltodextrina. Amostras contendo 0, 5, 10 e 15\% (m/m) de maltodextrina foram liofilizadas e o índice de fluxo, ângulos de atrito com parede e densidades foram determinados. A microestrutura dos pós foi avaliada por microscopia eletrônica de varredura (MEV). As amostras contendo 0 e $5 \%$ de maltodxtrina apresentaram Fl de 1,87 sendo classificadas como pós muito coesos e as amostras com 10 e $15 \%$ como coesos, com Fl de 2,12 e 2,43, respectivamente. As densidades dos pós variaram de 138,6 a 287,6 kg / m3 e o ângulo de atrito da parede entre 15,8 e 39, $8^{\circ}$. As partículas dos pós apresentaram formas irregulares e superfícies rugosas, principalmente em pós contendo 0, 5 e 10\% de maltodextrina. O pó contendo $15 \%$ apresentou superfícies mais lisas e menos aglomeradas. $O$ aumento da maltodextrina adicionada à polpa tornou as partículas mais lisas, mais densas e melhorou a fluidez do pó.
\end{abstract}

Termos para indexação: Índice de fluxo; coesividade; densidade de pó.

\section{INTRODUCTION}

Brazil's coconut industry is responsible for $4.8 \%$ of the world's total coconut production (Kanojia; Jain, 2017). The consumption of coconut water has increased worldwide and represents one of the fastest growing beverage categories due to its qualities, functional health properties and nutritional benefits and improvements in its taste (Prado et al., 2015). After removing the coconut water from the fruit, the industry frequently inappropriately discards the pulp, generating environmental problems (Soares et al., 2015). According to Soares et al. (2015), green dwarf coconut pulp has a lipid content of approximately $30 \%$, representing an interesting perspective as an ingredient in the segment of "light" foods.

The manipulation of food powders usually involves different operational processes, such as filling, flushing, flow, mixing, compaction and storage. Thus, it becomes important to understand the behaviour of the powder flow and analyse the surface of the particles to predict the behaviour during processing, as well as that throughout the 
life of commercialization of the product. To avoid some problems in the flow of powders, such as channelling, segregation and irregular flow, knowledge of the flow properties of the powders is important (Garg et al., 2018; Leturia et al., 2014).

Powder flowability is the capacity of a powder to flow under a specific set of conditions. It is a complex characteristic but not an inherent property of the powder because it depends not only on physical properties (particle size, particle shape, moisture content and surface roughness) but also on the powder's state of stress and on the equipment used to store, handle or process the powder (Vasilenko; Glasser; Muzzio, 2011).

The drying of foods that contain large amounts of sugars results in highly hygroscopic products. Therefore, it is fundamental to use drying aids to facilitate the dehydration and operations of transport and storage (Cai; Corke, 2000). There are many of these agents, but maltodextrin is the most commonly used, especially in fruit powders. Maltodextrin is the carrier agent commonly used in drying due to its high solubility, low hygroscopicity and low cost, in addition to its high glass transition temperature, which has facilitated its use as an additive in the industry (Mosquera; Moraga; Martinez-Navarrete, 2010). This carrier agent reduces the powder agglomeration and wall adherence in the dryer, in addition to improving its flow (Anakella; Orsat, 2013).

The objective of this work was to evaluate the flow and morphological characteristics of powders of lyophilized green coconut pulp (GCP) containing different concentrations of maltodextrin DE20.

\section{MATERIAL AND METHODS}

\section{Material preparation}

Frozen green coconut pulp (GCP) was obtained from a local market (Fortaleza, CE, Brazil). The pulps were packed in polyethylene bags, with $100 \mathrm{~g}$ in each, and frozen until the beginning of the experiments. Maltodextrin dextrose equivalent 20 (DE 20), purchased locally from Fortaleza-CE, was used as the drying aid.

Samples of coconut pulp were added to maltodextrin in the following proportions $(\mathrm{m} / \mathrm{m}): 0,5,10$ and $15 \%$ and homogenized. Afterwards, they were subjected to freezing and kept at $-38{ }^{\circ} \mathrm{C}$ for 24 hours in an ultra-freezer model CL 90-40V of the brand Terroni Scientific Equipment (São Carlos, Brazil).

After the freezing step, the frozen samples were transferred to an LS3000 lyophilizer of the brand Terroni
Scientific Equipment (São Carlos, Brazil), where they were lyophilized for $24 \mathrm{~h}$, reaching final pressures between 20 and $30 \mathrm{~Pa}$ and a final sample temperature of $25^{\circ} \mathrm{C}$. After drying, the samples were ground with a brand MA 048 - Marconi mill (São Paulo, Brazil) to obtain powders. The resulting powders were vacuum packed in a PET, aluminium and polyamide laminated package until the start of the analysis.

\section{Flow property methods}

In the evaluation of the flow of the powders, the principal consolidation and unconfined sliding tensions, the apparent densities and the wall friction angles (stainless steel) were determined through the powder flow test (PFT) by Brookfield Engineering Laboratories (Massachusetts, EUA). Powder samples (20 g) containing $0,5,10$ and $15 \%(\mathrm{w} / \mathrm{w})$ maltodextrin DE20, in duplicate, were placed in stainless steel circular trays. Then, the samples were transferred to the PFT, which applied stress to the surface of the powders through a circular stainless steel disk to measure the flow parameters. The normal stress applied to the sample surfaces ranged from 0 to $13.5 \mathrm{kPa}$, and the shear stress ranged from 0 to $5 \mathrm{kPa}$. To classify the flow of powders, the flow index (FI) was used according to Equation 1 and Table 1 (Lopes Neto et al., 2007).

$F I=\frac{\sigma_{1}}{\sigma_{C}}$

where FI represents the flow index, $\sigma_{1}$ is the principal consolidation stress average $(\mathrm{kPa})$ and $\sigma_{\mathrm{c}}$ is the unconfined failure strength average $(\mathrm{kPa})$.

Table 1: Classification of the type of flowability of storable solid products.

\begin{tabular}{cc}
\hline Type of flow & Flow index $(\mathrm{Fl})$ \\
\hline Non-flowing & $\mathrm{Fl}<1$ \\
Very cohesive & $1<\mathrm{Fl}<2$ \\
Cohesive & $2<\mathrm{Fl}<4$ \\
Easy flowing & $4<\mathrm{Fl}<10$ \\
Free flowing & $>10$ \\
\hline
\end{tabular}

\section{Morphological analysis}

For the morphological evaluation of the powders, the samples were deposited on double-sided adhesive tape, fixed in a metallic support and covered with platinum and 
gold with a metallizer brand Quorum Q 1550T ES (Lewis, Inglaterra). Micrographs with 350x resolution were obtained using a Quanta FEG 450 - FEI Company (EUA) scanning electron microscope (SEM). The GCP powder samples containing $0,5,10$ and $15 \%(\mathrm{w} / \mathrm{w})$ maltodextrin DE20 were evaluated.

\section{RESULTS AND DISCUSSION}

The test to which the powders were subjected is composed of a cylindrical shear cell, placed on the base of the machine, which together with weights is used for the application of a vertical load by gravity, and a load support with an electromechanical drive provides horizontal movement at a given velocity, which is responsible for generating the initial shear. Table 2 shows the values found in relation to the principal consolidation stresses $\left(\sigma_{1}\right)$ and the unconfined sliding stresses $\left(\sigma_{c}\right)$ for the GCP powder samples.

The higher the value of the unconstrained slip stress $\left(\sigma_{c}\right)$ of a powder is, the lower its flowability, that is, the more difficult it is for the powder to flow (Lopes Neto et al., 2007). Although the unconstrained slip tension $\left(\sigma_{c}\right)$ was influenced by the principal stress $\left(\sigma_{1}\right)$, it was observed that the concentration of maltodextrin strongly influenced the values of $\sigma_{c}$ (Table 2). As the concentration of maltodextrin increased, a decrease occurred in this stress $\left(\sigma_{c}\right)$, demonstrating that the addition of the drying aid directly influenced the flowability of the powders. Rocha et al. (2017) evaluated the flow of maltodextrin-added mango pulp, and the same trend was observed of a decrease in the unconstrained sliding tension that was inversely proportional to the adjuvant addition.

From Equation 1 and the values of the stresses (Table 2), the sample flow indexes (FI) were determined. The flow index of the samples containing 0 and $5 \%$ maltodextrin was 1.87 , which according to Lopes Neto et al. (2007), indicates very cohesive powders. The powders with additions of 10 and $15 \%$ presented cohesive FI values of 2.12 and 2.43, respectively. Ostrowska-Ligęza and Lenart (2015), in studying the flow of cocoa powder with different levels of water activities, classified the powders as cohesive or very cohesive, similar to those of this work. The cohesion of the particles of a powder is mainly caused by forces between the particles, such as van der Waals forces. The fluidity of the powder is also explained in terms of adhesion or inter-particulate adhesion, which is affected by the high sugar content in foods (Seerangurayar et al., 2017).

The variation in GCP powder densities was obtained by PFT through the application of normal stress to the sample surfaces. Figure 1 shows the behaviour of the density in relation to the stresses applied to the powders. As the normal stresses applied by the PFT on the GCP powder samples increased, the densities increased. Oliveira et al. (2013) state that the density takes into account the volume of the spaces present between the particles; in this way, the greater the density is, the smaller the amount of occluded air. According to Campos and Ferreira (2013), the increase in the density of a powder as a function of the applied stresses is the result of its compaction (tapped density). Increasing the normal stress on the powder particles tends to eliminate the occluded air, increasing the density.

The bulk and tapped densities are presented in Table 3 . The density values were lower than those observed by Maciel et al. (2020) for cupuaçu powder samples containing 10 to $25 \%$ maltodextrin, with bulk densities from 226.4 to $322.7 \mathrm{~kg} / \mathrm{m}^{3}$ and tapped densities from 383.3 to $536.6 \mathrm{~kg} / \mathrm{m}^{3}$. The higher densities of cupuaçu pulp powder may be due to the high content of soluble solids in this type of powder.

Table 2: Strength of coconut pulp powders mixed with $0,5,10$ and $15 \%$ maltodextrin.

\begin{tabular}{cccccccc}
\hline \multicolumn{7}{c}{ Maltodextrin concentration } \\
\multicolumn{2}{c}{$0 \%(\mathrm{w} / \mathrm{w})$} & \multicolumn{2}{c}{$5 \%(\mathrm{w} / \mathrm{w})$} & \multicolumn{2}{c}{$10 \%(\mathrm{w} / \mathrm{w})$} & \multicolumn{2}{c}{$15 \%(\mathrm{w} / \mathrm{w})$} \\
\hline $\begin{array}{c}\sigma_{1} \\
(\mathrm{kPa})\end{array}$ & $\begin{array}{c}\sigma_{c} \\
(\mathrm{kPa})\end{array}$ & $\begin{array}{c}\sigma_{1} \\
(\mathrm{kPa})\end{array}$ & $\begin{array}{c}\sigma_{c} \\
(\mathrm{kPa})\end{array}$ & $\begin{array}{c}\sigma_{1} \\
(\mathrm{kPa})\end{array}$ & $\begin{array}{c}\sigma_{c} \\
(\mathrm{kPa})\end{array}$ & $\begin{array}{c}\sigma_{1} \\
(\mathrm{kPa})\end{array}$ & $\begin{array}{c}\sigma_{c} \\
(\mathrm{kPa})\end{array}$ \\
\hline 1.673 & 1.455 & 1.906 & 1.253 & 1.310 & 0.938 & 1.642 & 0.861 \\
4.723 & 2.477 & 3.949 & 1.963 & 3.355 & 1.477 & 3.479 & 1.622 \\
9.405 & 4.830 & 8.361 & 4.362 & 7.516 & 3.760 & 7.782 & 3.041 \\
20.018 & 10.430 & 15.428 & 8.289 & 14.081 & 6.188 & 15.664 & 6.235 \\
\hline
\end{tabular}

$\sigma_{1}-$ Principal consolidation stress; $\sigma_{c}-$ Unconfined failure strength. 


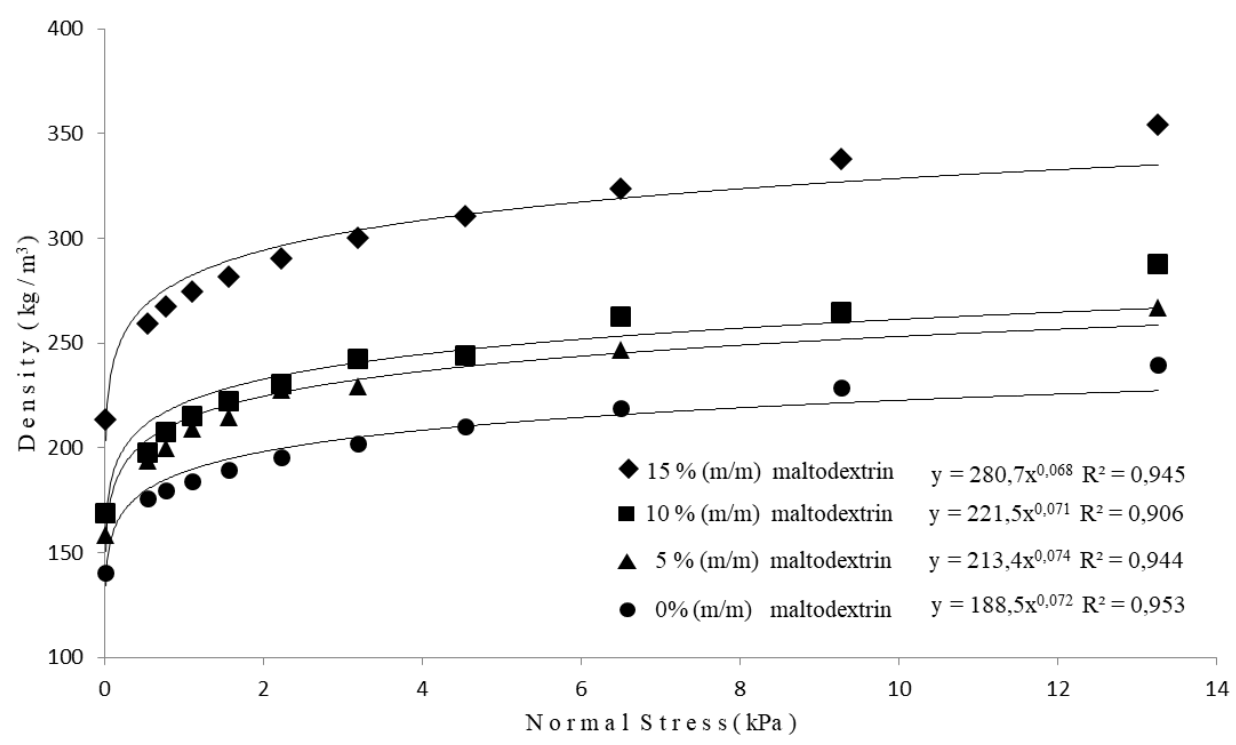

Figure 1: Density of coconut pulp powders obtained by freeze-drying containing $0,5,10$ and $15 \%$ maltodextrin as a function of the normal stress.

It was observed (Table 3) that an increase in the concentration of maltodextrin increased the sample densities (bulk and tapped). Zhao et al. (2009) and Farahnaky et al. (2016) also observed this trend of increasing density by studying dried ginger powder and syrup powders with different concentrations of oven-dried maltodextrin, respectively. Rocha et al. (2017) observed the same behaviour when evaluating mango pulp powder containing between 10 and $30 \%$ maltodextrin. These results are due to the decrease in the formation of voids between the particles (Seerangurayar et al., 2017; Tontul; Topuz, 2017), which may be attributed to the changes in the particle shape and their surfaces as a result of maltodextrin addition.

Table 3: Density $\left(\mathrm{kg} / \mathrm{m}^{3}\right)$ and wall friction angle $\left({ }^{\circ}\right)$ of coconut pulp powders containing 0, 5, 10 and 15\% $(\mathrm{m} / \mathrm{m})$ maltodextrin.

\begin{tabular}{ccccc}
\hline \multirow{2}{*}{ Samples } & \multicolumn{2}{c}{ Density $\left(\mathrm{kg} / \mathrm{m}^{3}\right)$} & \multicolumn{2}{c}{ Wall friction angle $\left(^{\circ}\right)$} \\
\cline { 2 - 5 } & bulk & tapped & lower & upper \\
\hline $0 \%$ & 140.5 & 239.8 & 28.0 & 39.8 \\
$5 \%$ & 158.7 & 267.0 & 21.7 & 33.5 \\
$10 \%$ & 169.1 & 287.6 & 21.2 & 33.2 \\
$15 \%$ & 213.4 & 354.6 & 15.8 & 21.0 \\
\hline
\end{tabular}

According to Santos, Condotta and Ferreira (2017), the more powder moisture there is, the greater the cohesive forces, resulting in the formation of agglomerates, which may contain air in the interior, reducing the density. Thus, the lower the maltodextrin concentration is, the higher the moisture content and the lower the density. Tonon, Brabet and Hubinger (2013) states that a maltodextrin addition increases the powder weight and more easily settles in the spaces between the particles, occupying less volume and resulting in greater density.

Aziz et al. (2018) reported that the drying method as well as the powder composition, namely, the presence of drying adjuvants, can influence the flowability of the powders. Thus, the increase in the concentration of maltodextrin increased the sample densities and modified the particle surface and shape, improving their flowability. This may be one of the reasons that several authors associate an increase in the powder density with better flow. According to Seerangurayar et al. (2017), the powder density is useful for predicting the quality of the particles since higher densities indicate that the powders have better properties, such as lower moisture content, higher yield, and good fluidity. Bicudo et al. (2015) states that density influences other powder properties, such as fluidity and solubility. High density is desirable to reduce shipping and packaging costs (Marques et al., 2014).

Regarding the wall friction angle (Table 3), it was observed that increasing concentration of maltodextrin in the formulation resulted in lower values, and the smallest friction angles were observed in the sample containing $15 \%$ maltodextrin. This behaviour was possibly caused by 
the effect of maltodextrin on the particle surfaces, making them smoother (Figure 2). Rocha et al. (2017), when evaluating spray-dried mango pulp powder containing 10 and $20 \%$ maltodextrin, observed the same behaviour and reported lower and upper angle values of 17.4 and $22.5^{\circ}$ and 15.6 and $19.3^{\circ}$, respectively. Afonso et al. (2019) obtained similar behaviour and measured lower and upper angle values of 14.9 and $18.9^{\circ}$ for freeze-dried mango pulp powder containing $15 \%$ maltodextrin. Seerangurayar et al. (2017) observed that in date powder with maltodextrin and gum arabic, as the concentration of the adjuvants increased, the wall friction angle decreased. The friction between a powder and a wall is related to the resistance to flow existing between the powder particles and the wall material. Fitzpatrick et al. (2004) stated that the wall friction angle represents the adhesive strength between the powder and the wall material of the storage environment, and the higher the strength is, the more difficult it is for the powder to move along the wall. Thus, the smaller the values of this angle are, the smaller the wall inclinations needed to ensure the flow of the powders. Knowledge of the friction in the wall is critical since it is an important parameter for determining the minimum angle required for a consistent and reliable flow (Juarez-Enriquez et al., 2017; Iqbal; Fitzpatrick, 2006).

The sample micrographs of the coconut pulp powders containing maltodextrin are shown in Figure 2. The particles showed curved edges in the 0 and $5 \%$ maltodextrin samples (Figure 2A and 2B) and showed more agglomeration than the 10 and $15 \%$ maltodextrin samples (Figure 2C and 2D).

According to Shaaruddin et al. (2017) and Pai et al. (2015), agglomeration has been reported to be typical in powders rich in polysaccharides. It was also observed that all the samples presented irregular shapes and/or rough surfaces, but the sample containing $15 \%$ maltodextrin
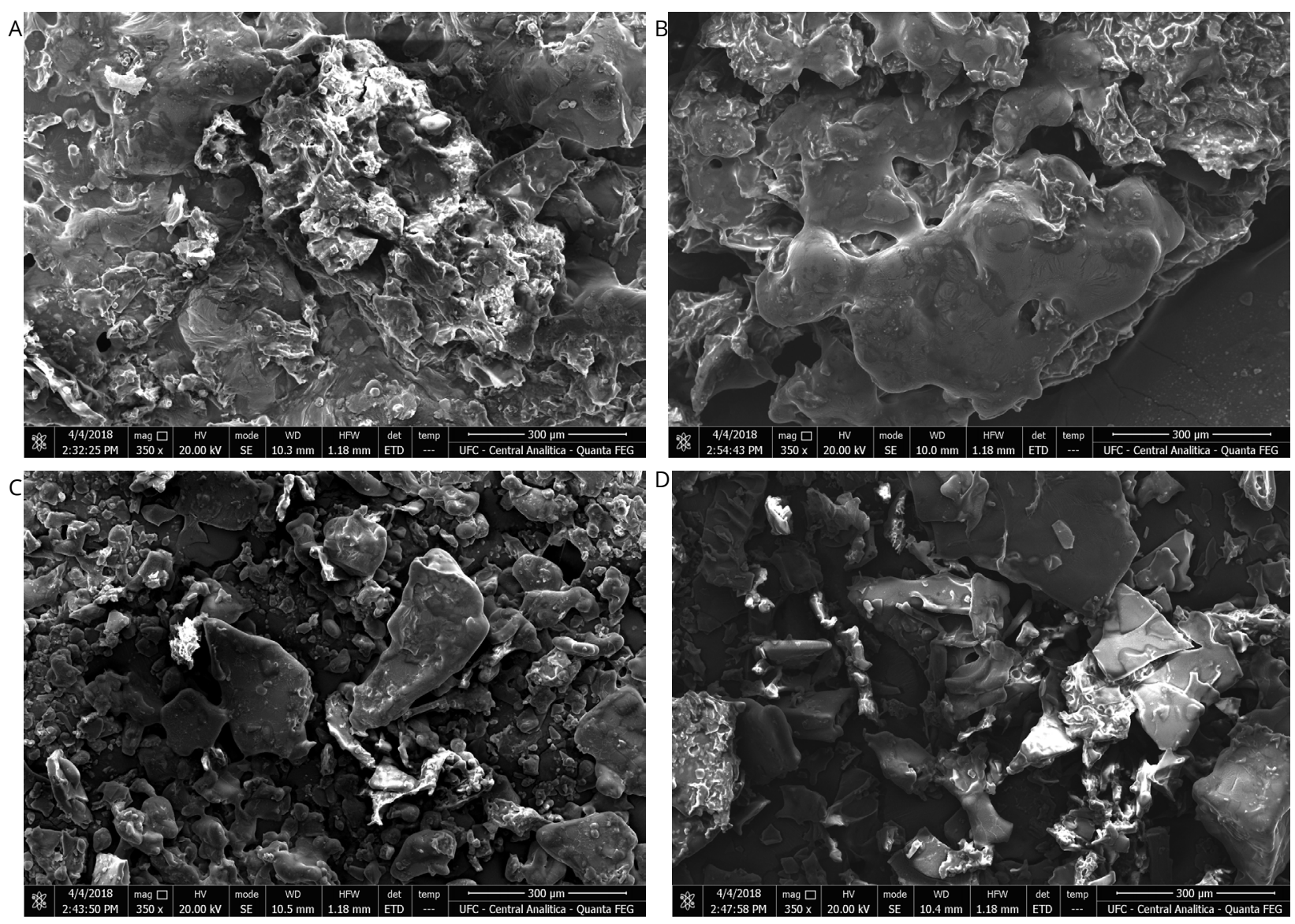

Figure 2: Scanning electron microscopy micrographs (350x) of freeze-dried GCP powder containing 0, (A), 5\% (B), $10 \%(C)$ and $15 \%(D)$ maltodextrin. 
(Figure 2D) presented more separated particles and smoother surfaces. Saikia, Mahnot and Mahanta (2015) and Kuck and Noreña (2016) studied the effect of spray drying and lyophilization on the surface of the particles of star fruit and grapefruit peel powders, reporting that in the spray, the particles were spherical in shape with concavities, whereas lyophilized powders had irregular, porous and brittle structures. According to Figure 2, the samples with the lowest amount of maltodextrin (5 and $10 \%$ ) were agglomerated, and it was not possible to clearly observe the irregularities in the surface of the lyophilized powder. In the sample containing $15 \%$ maltodextrin, the agglomeration decreased considerably, allowing the visualization of irregular and brittle particles. The increase in maltodextrin concentration in the formulation of the samples caused changes in the particles' state of segregation and surfaces, which became smoother and less agglomerated as the maltodextrin concentration increased. This behaviour, according to Tonon, Brabet and Hubinger (2009), can improve the flow characteristics of the powder.

\section{CONCLUSIONS}

The addition of maltodextrin to the green coconut pulp (GCP) altered the characteristics of the powder. Maltodextrin increased the density of the powder and decreased the wall friction angle. In addition, it altered the powder microparticles, making them smoother and less agglomerated. Thus, the addition of maltodextrin increased the powder flow.

\section{ACKNOWLEDGEMENTS}

The project was supported by the Coordenação de Aperfeiçoamento de Pessoal de Nível Superior - Brasil (CAPES) and Conselho Nacional de Desenvolvimento Científico e Tecnológico (CNPq).

\section{REFERENCES}

AFONSO, M. R. et al. Microstructure and flow properties of lyophilized mango pulp with maltodextrin. Revista Brasileira de Engenharia Agrícola e Ambiental, 23(2):133-137, 2019.

ANAKELLA, K.; ORSAT, V. Optimization of microencapsulation of probiotics in raspberry juice by spray drying. LWT - Food Science and Technology, 50(1):17-24, 2013.

AZIZ, M. et al. Material properties and tableting of fruit powders. Food Engineering Reviews, 10:66-80, 2018.
BICUDO, M. O. P. et al. Microencapsulation of Juçara (Euterpe edulis M.) pulp by spray drying using different carriers and drying temperatures. Drying Technology, 33(2):153-161, 2015.

CAI, Y. Z.; CORKE, H. Production and properties of spray-dried Amaranthus betacyanin pigments. Journal of Food Science, 65(7):1248-1252, 2000.

CAMPOS, M. M.; FERREIRA, M. C. A comparative analysis of the flow properties between two alumina-based dry powders. Advances in Materials Science and Engineering, 4:1-7, 2013.

FARAHNAKY, A. et al. Physicochemical and sorption isotherm properties of date syrup powder: Antiplasticizing effect of maltodextrin. Food and Bioproducts Processing, 98:133141, 2016.

FITZPATRICK, J. J. et al. Effect of powder properties and storage conditions on the flowability of milk powders with different fat contents. Journal of Food Engineering, 64(4):435-444, 2004.

GARG, V. et al. An investigation into the flowability of fine powders used in pharmaceutical industries. Powder Technology, 336: 375-382, 2018.

IQBAL, T.; FITZPATRICK, J. J. Effect of storage conditions on the wall friction characteristics of three food powders. Journal of Food Engineering, 72(3):273-280, 2006.

JUAREZ-ENRIQUEZ, E. et al. Effect of water content on the flowability of hygroscopic powders. Journal of Food Engineering, 205:12-17, 2017.

KANOJIA, A.; JAIN, S. K. Performance of coconut shell as coarse aggregate in concrete. Construction and Building Materials, 140:150-156, 2017.

KUCK, L. S.; NOREÑA, C. P. Z. Microencapsulation of grape (Vitis labrusca var. Bordo) skin phenolic extract using gum arabic, polydextrose, and partially hydrolyzed guar gum as encapsulating agents. Food Chemistry, 194:569-576, 2016.

LETURIA, M. et al. Characterization of flow properties of cohesive powders: A comparative study of traditional and new testing methods. Powder Technology, 253:406-423, 2014.

LOPES NETO, J. P. et al. Flow properties and flowability characteristics of poultry rations for silos design. Ciência e Agrotecnologia, 31(3):851-859, 2007.

MACIEL, R. M. G. et al. Influence of maltodextrin on the flow properties of the cupuaçu pulp poder. Brazilian Journal of Development, 6(2):5829-5839, 2020. 
MARQUES, G. R. et al. Application of maltodextrin in green corn extract powder production. Powder Technology, 263:89-95, 2014.

MOSQUERA, L. H.; MORAGA, G.; MARTINEZ-NAVARRETE, N. Effect of maltodextrin on the stability of freeze-dried borojó (Borojoa patinoi Cuatrec.) powder. Journal of Food Engineering, 97:72-78, 2010.

OLIVEIRA, M. I. S. et al. Stability of atomized strawberry pulp using different carriers agents. Brazilian Journal of Food Technology, 16(4):310-318, 2013.

OSTROWSKA-LIGĘZA, E.; LENART, A. Influence of water activity on the compressibility and mechanical properties of cocoa products. LWT - Food Science and Technology, 60(2):10541060, 2015.

PAI, D. A. et al. Resistant maltodextrin as a shell material for encapsulation of naringin: Production and physicochemical characterization. Journal of Food Engineering, 161:68-74, 2015.

PRADO, F. C. et al. Development and evaluation of a fermented coconut water beverage with potential health benefits. Journal of Functional Foods, 12:489497, 2015.

ROCHA, F. O. et al. Influence of maltodextrin on the flow properties of mango powder. Higiene Alimentar, 31:43724376, 2017.

SAIKIA, S.; MAHNOT, N. K.; MAHANTA, C. L. Optimization of phenolic extraction from Averrhoa carambola pomace by response surface methodology and its microencapsulation by spray and freeze drying. Food Chemistry, 171:144-152, 2015.
SANTOS, L. C.; CONDOTTA, R.; FERREIRA, M. C. Flow properties of coarse and fine sugar powders. Journal of Food Process Engineering, 41(2):1-10, 2017.

SEERANGURAYAR, T. et al. Effect of carrier agents on flowability and microstructural properties of foam-mat freeze dried date powder. Journal of Food Engineering, 215:33-43, 2017.

SHAARUDDIN, S. et al. Stability of betanin in pitaya powder and confection as affected by resistant maltodextrin. LWT - Food Science and Technology, 84:129-134, 2017.

SOARES, G. L. et al. Caracterização físico-química de polpa de coco verde submetida ao congelamento lento e rápido. Nativa, 3(3):185-190, 2015.

TONON, R. V.; BRABET, C.; HUBINGER, M. D. Aplicação da secagem por atomização para a obtenção de produtos funcionais com alto valor agregado a partir do açaí. Inclusão Social, 6(2):70-76, 2013.

TONON, R. V.; BRABET, C.; HUBINGER. M. D. Influência da temperatura do ar de secagem e da concentração de agente carreador sobre as propriedades físico-químicas do suco de açaí em pó. Ciência e Tecnologia de Alimentos, 29(2):444-450, 2009.

TONTUL, I.; TOPUZ, A. Spray-drying of fruit and vegetable juices: Effect of drying conditions on yield and physical properties. Trends in Food Science \& Technology, 63:91-102, 2017.

VASILENKO, A.; GLASSER, B. J.; MUZZIO, F. J. Shear and flow behavior of pharmaceutical blends - Method comparison study. Powder Technology, 208(3):628-636, 2011.

ZHAO, X. et al. Effect of superfine grinding on properties of ginger powder. Journal of Food Engineering, 91(2):217222, 2009. 